\title{
EXAMINE THE MEDIATING EFFECT OF WORK-LIFE BALANCE ON THE RELATIONSHIP BETWEEN WORK-FAMILY CONFLICT AND JOB SATISFACTION OF WOMEN DOCTORS
}

\author{
Harjot Kaur \\ Research scholar, Department of USAM, Punjabi university Patiala, India \\ Dr. Sarang Narula \\ Assistant professor, Department of USAM, Punjabi University Patiala, India
}

\begin{abstract}
The objective of present study was to examine work-life balance in the relation between conflict (work-family conflict) and job satisfaction among female doctors. Confirmatory factor analysis (CFA) was used to check the reliability and validity of the scales. SEM was applied to test the mediating effect of work-life balance between conflict (work-family conflict) and job satisfaction with the sample of 200 female doctors. Data collected from four groups of ages (25-29, 30-39, 40-49 and 50 above) and majority of the participants lie in 30-49 age group. Results of SEM analysis found that the effect of conflict on work-life balance and job satisfaction was negative but significant as $b 1=-0.913, t=41.78(p<.01)$. The effect of mediator work-life balance on the job-satisfaction was significant as $b 2=0.47$. In addition, conflict may negatively affect the job satisfaction directly or through work-life balance. Work-life balance fully mediates the relationship between conflict and job satisfaction.
\end{abstract}

Keywords: Work-life balance, conflict, work-family conflict, family-work conflict, job satisfaction, female, Doctors.

Cite this Article: Harjot Kaur and Dr. Sarang Narula, Examine the Mediating Effect of Work-Life Balance on the Relationship between Work-Family Conflict and Job Satisfaction of Women Doctors, International Journal of Management, 11(6), 2020, pp. 2131-2138

http://iaeme.com/Home/issue/IJM?Volume $=11 \&$ Issue $=6$ 


\section{INTRODUCTION}

Economic, political and social changes have had an effect on working lives of individuals. Increasing living standards and the importance of work and personal life have reinforced the demands of individuals on work and family (McCarthy, Hill \& Grady 2012; Kurtuldu \& Ozkara, 2013; Chandra, 2012). Work and personal life both are closer and affect to each other, bidirectional in nature (Hill, Hawkins, Ferris \& Weitzman, 2001). Balancing work and family demands is a major challenge for individuals and organizations and it has been indicated that an individual's best interests are offered by living a balanced life (Valcour 2007; Kofodimos 1993).Various factors affects the work-life balance like changing demographics, time demands, responsibilities related to family and work which have induced interest towards work-family balance (Aryee, Srinivas and Tan 2005; Perrons 2003; Reich 2001). Work -life imbalance leads to conflict (Greenhaus \& Beutell 1985). Work-family conflict arises when work interfere in family as well as family interfere in work. Such pressures in work and family might be role overload, irregular working hours, job stress, unsupportive supervisor and family members, responsibilities of children and elder (Greenhaus 2002; Chernyak \& Tziner, 2016). Previous studies found that work-family conflict have significant negative correlation with job satisfaction and psychological wellbeing (Hughes \& Galinsky, 1994; Kinnunen \& Mauno, 1998; Frone, Russell \& Cooper, 1992; Kossek \& Ozeki, 1998; Mesmer- Maguns \& Viswesvaran, 2005).

In present stressful business environment, there is greater demand for medical and health services. Although, shortage of doctors and expanding number of patients lead to a greater work burden for doctors (Abidin et al., 2010). Orrom, 2008 showed that the amount of time and energy used for work is sixty two percent when the importance of work is only thirty percent in a person life. Over workload is related with poor work-life balance and reduced job satisfaction which is common among doctors that results negative ramifications on patients' safety and increased medical errors (Michtalik et al., 2013). Multiple roles and responsibilities at work and home lead to work-family conflict among female doctors and face an immense amount of stress.

\section{THEORETICAL BACKGROUND}

\subsection{Conflict}

Work-family conflict occurred when demand connected with one domain are incompatible with other domain (Greenhaus \& Buetell, 1985; Kopelman \& Connolly, 1983). Work-family conflict arises because of incompatibility or non-fulfillment of demands of two domains namely work and family where the fulfillment the demand of one domain, the demand of other domain remains unfulfilled. Literature reveals three aspects of conflict viz. time based conflict, behavioral based conflict and strain based conflict. Time based conflict occurs with the excessive work time and schedule conflict dimensions identified by Pleck et.al, (1980) and work stressor can produce strain symptoms such as depression, fatigue, unconcern (Ivancevich \& Matteson, 1980; Brief \& Schuler Van Sell, 1981). Greenhaus and Beutell, 1985 defined when one role behavior becomes incompatible with expectation regarding behavior in another role then behavior conflict occurred. Work-family conflict related to negative work attitude (Frone et.al, 1992; Yang et.al, 2000), leaving work early (Burke et.al. 2005), absenteeism (Golf et.al, 1990), turnover intentions (Bruck, 2002), higher psychological stress (Frone 2003), lower job satisfaction (Kossek and Ozeki 1998) and other negative work behavior. Both work interfere family and family interfere work forms had shown negative impact on family, organization and personal outcomes. 
Examine The Mediating Effect of Work-Life Balance on the Relationship Between WorkFamily Conflict and Job Satisfaction of Women Doctors

\subsection{Work life balance}

It was first defined as low level of conflict between work and family (Hill et.al, 2001), has been examined as an independent factor of conflict. Greenhaus \& Allen (2006) describe work-life balance is the degree to which a person's effectiveness and satisfaction in family and work roles are compatible with a person's life priorities at the given point of time (Greenhauus Collins \& shaw 2003). Work-life balance is phrase used in the literature to acknowledgement the policies that attempt to attain a greater harmony as well as balance between work and family responsibilities (Redmond, Valiulis \& Drew, 2006). It is significant for a person psychological well-being. High self-esteem, satisfaction, and sense of reconciliation in life can be regarded as pointers of a positive balance between job and life roles Clark (2000); Clarke, Koch and Hill (2004); Marks and Mac Dermid, 1996). The successful work-life balance initiatives reduce job turnover, stress levels, conflict and enhances job satisfaction among individuals (Purohit, 2013). The objective of present study is to test the mediating role of work-life balance between workfamily conflict and job satisfaction. The mediation model in present study helps in understanding how work-family conflict is related to the outcome variable job satisfaction through work-life balance as mediator.

\section{JOB SATISFACTION}

Job satisfaction is mostly considered to represent the contribution of an individual's attitude toward the job. It refers to a person's feelings of satisfaction on the job which work as a motivation. Job satisfaction is concept includes the extent to which people like or dislike in their job. Job satisfaction is related to the fulfillment of expectation of an individual regarding their work which indicates more satisfied work has higher fulfillment of expectation than less satisfaction or no satisfaction worker (Spector, 2000). Job satisfaction defined as a pleasure or positive emotional state resulting from the appraisal of one's job experience (Locke, 1976). Job satisfaction is an emotional response to a job situation which can only inferred, determined by how well outcomes meet expectation. Most important characteristics of a job such as work itself, supervision, co-workers, pay represents several related attitude about job (Luthans, 1998). Previous studied has defined that job satisfaction is the attitude which feel an employee regarding his job. It is determined as extent to which people happy with their job and work environment. Researcher studied that employees who are more satisfied are more likely to produce a higher standard of work performance (Tumulty et.al., 1994) and remain with the organization (Brayfield and Rothe 1951).

\section{RESEARCH MODEL}

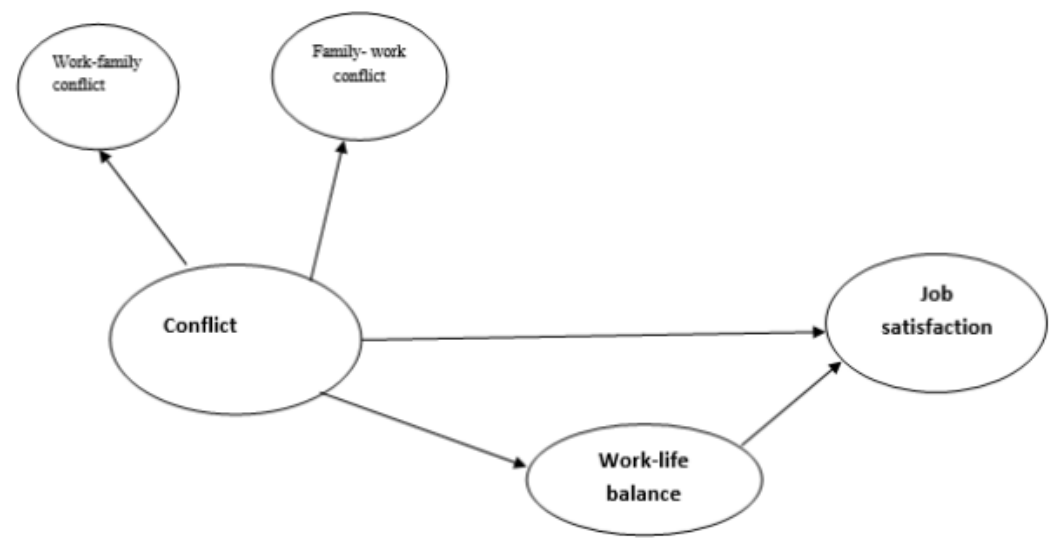

Figure 1 Conflict 


\subsection{Research Setting}

The present study is carried out with 200 female doctors comprise $54.5 \%$ working in private hospitals and $45.5 \%$ in government hospital. The participants are working in well reputed multispecialty hospitals in different areas of Punjab. Participants were divided into four groups of ages $(25-29,30-39,40-49$ and 50 above) and majority of participants lie in 30-49 age group. The sample displayed most of the respondent were married (71.8\%) and 24.2\% were unmarried. All female doctors' qualifications were post graduate.

\subsection{Measurement}

\subsubsection{Reliability and Validity of the Scales}

Confirmatory factor analysis (CFA) was used to check the reliability and validity of the scales. Standardized scales were used for collect the data. Table 1 showed the factors which was extracted using factor analysis and the variance explained by these factors. In the analysis initially 42 items were measuring 3 constructs. During the factor analysis few of the items were removed due to poor factor loadings and finally 35 were retained. In the following table we can be seen that none of the factor loading is below .6.

Table 1 factor loadings of CFA model

\begin{tabular}{|c|c|c|c|c|c|}
\hline & Conflict & $\begin{array}{c}\text { Family } \\
\text { interference in } \\
\text { work }\end{array}$ & $\begin{array}{c}\text { Work } \\
\text { Interference in } \\
\text { family }\end{array}$ & $\begin{array}{c}\text { Work life } \\
\text { balance }\end{array}$ & Job Satisfaction \\
\hline wfc10 & 0.874 & 0.874 & & & \\
\hline wfc11 & 0.873 & 0.906 & & & \\
\hline wfc12 & 0.864 & 0.912 & & & \\
\hline wfc13 & 0.904 & 0.948 & & & \\
\hline wfc14 & 0.908 & 0.926 & & & \\
\hline wfc15 & 0.910 & 0.933 & & & \\
\hline wfc16 & 0.657 & 0.608 & & & \\
\hline wfc18 & 0.488 & 0.635 & & & \\
\hline wfc1 & 0.886 & & 0.921 & & \\
\hline wfc2 & 0.898 & & 0.938 & & \\
\hline wfc3 & 0.873 & & 0.923 & & \\
\hline wfc4 & 0.839 & & 0.883 & & \\
\hline wfc5 & 0.838 & & 0.864 & & \\
\hline wfc6 & 0.884 & & 0.918 & & \\
\hline wfc9 & 0.839 & & 0.827 & & \\
\hline wlb1 & & & & 0.926 & \\
\hline wlb2 & & & & 0.953 & \\
\hline wlb3 & & & & 0.956 & \\
\hline wlb4 & & & & 0.957 & \\
\hline wlb5 & & & & 0.967 & \\
\hline wlb6 & & & & 0.953 & \\
\hline wlb7 & & & & 0.962 & \\
\hline wlb8 & & & & 0.964 & \\
\hline wlb9 & & & & 0.966 & \\
\hline JS1 & & & & & 0.670 \\
\hline JS10 & & & & & 0.642 \\
\hline JS11 & & & & & 0.600 \\
\hline JS12 & & & & & 0.652 \\
\hline JS14 & & & & & 0.834 \\
\hline
\end{tabular}


Examine The Mediating Effect of Work-Life Balance on the Relationship Between WorkFamily Conflict and Job Satisfaction of Women Doctors

\begin{tabular}{|c|c|c|c|c|c|}
\hline & Conflict & $\begin{array}{c}\text { Family } \\
\text { interference in } \\
\text { work }\end{array}$ & $\begin{array}{c}\text { Work } \\
\text { Interference in } \\
\text { family }\end{array}$ & $\begin{array}{c}\text { Work life } \\
\text { balance }\end{array}$ & Job Satisfaction \\
\hline JS15 & & & & & 0.762 \\
\hline JS5 & & & & & 0.803 \\
\hline JS6 & & & & & 0.740 \\
\hline JS7 & & & & & 0.839 \\
\hline JS8 & & & & & 0.761 \\
\hline JS9 & & & & & 0.734 \\
\hline
\end{tabular}

\subsubsection{Reliability and Validity of Constructs}

The reliability of the constructs was examined using Composite reliability and Cronbach's alpha. The composite reliability of all of the constructs was above 0.7 . The factors were stated to be adequately reliable as alpha value of all the constructs was greater than 0.9. AVE of all constructs was well above 0.5 . The discriminant validity was examined using inter-construct correlations and AVE. AVE of all the construct is significantly higher than 0.5 .

Table 2 - Inter-constructs correlations

\begin{tabular}{|c|c|c|c|c|c|}
\hline & 苂 & 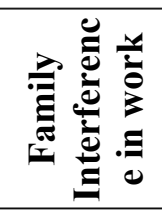 & 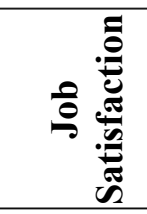 & 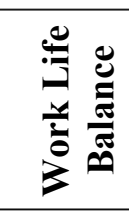 & 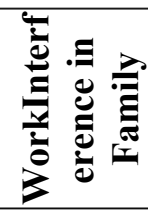 \\
\hline Conflict & 1 & 0 & 0 & 0 & 0 \\
\hline Family Interference in work & 0.964 & 1 & 0 & 0 & 0 \\
\hline Job Satisfaction & -0.708 & -0.626 & 1 & 0 & 0 \\
\hline Work Life Balance & -0.913 & -0.869 & 0.685 & 1 & 0 \\
\hline Work Interference in Family & 0.966 & 0.861 & -0.737 & -0.892 & 1 \\
\hline
\end{tabular}

\section{METHODOLOGY}

H1: work-life balance mediates the relationship between conflict and job satisfaction.

Figure 1 showed the conflict is the independent variable, work-life balance is the mediator and job-satisfaction is the dependent variable. The results of the analysis showed that the effect of conflict on the mediator variable work-life balance was significant as $b 1=(-) 0.913, t=$ $41.78(\mathrm{p}<.01)$ and suggested that as conflict (work-family conflict) increased, the work-life balance decreased significantly. The effect of mediator variable work-life balance on the dependent variable job-satisfaction was significant $b 2=0.47$. This means as the work-life balance affect the job satisfaction of female doctors. As it can be seen in the following model indirect effects results showed that work-life balance mediate the relationship between conflict (work-family conflict) and job satisfaction. The results also revealed that conflict may negatively affect the job satisfaction directly and also through work-life balance. 


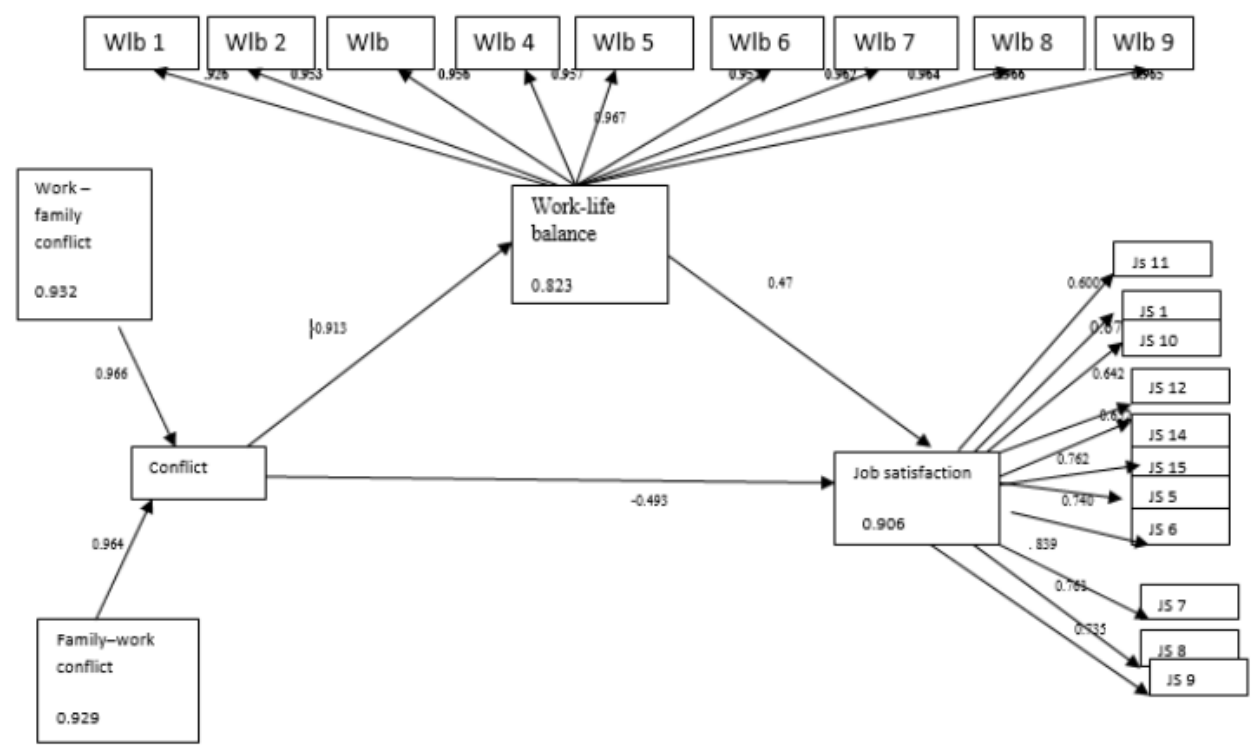

Figure 2 model estimating the mediating role of work-life balance between conflit and job-satisfaction

\section{DISCUSSION, LIMITATION AND FUTURE RESEARCH}

The present study examined the effect of conflict and work-life balance on job satisfaction. The findings of the study indicated that conflict was negatively related with work-life balance and job satisfaction. Work-life balance also the job satisfaction of female doctors. Furthermore, results concluded that fully mediation of work-life balance on the relationship between conflict and job satisfaction. Conflict may negatively affect the job satisfaction directly or through work life balance. There are the various reasons such as irregular working hours, night shifts, on call duty and emergency etc. that makes the job difficult whereas, create conflict among female doctors. The results of the study are verified with the previous studies that conflict had negatively effect on work-life balance and job satisfaction among female doctors (Greenhaus et.al., 2002; Haar, 2013; Haar et.al., 2014, Karckay et.al., 2017, Wright and Bonett, 1997). Our study also concluded that work-life balance has a similar mediating effect that found by Haar, 2013; Karckay and Bakalim, 2017). The present research is only related to female doctors working in selected public and private hospitals from some cities of Punjab only. It excludes the females who are employees in other hospitals and sector. Future research must focus on large sample, other hospitals and male doctors, nurses also considered in order to achieve more generalized results. There are many variable related to effect of work-life balance and conflict such as age, patient care, parenting status, gender, marital status etc. and other dimensions of conflict which should be considered in future research.

\section{REFERENCES}

[1] Abidin, A.Z., Zulkifli, C.M. and Nordin, J. (2010) 'Family Issues and WorkFamily Conflict among Medical Officers in Malaysian Public Hospitals', International Journal of Business and Social Science, Vol. 1(1), pp. 26-36.

[2] Aryee, S., Srinivas, E.S., and Tan, H.H. (2005), "Rhythms of life: Antecedents and Outcomes of Work-Family Balance in Employed Parents," Journal of Applied Psychology, 90, 1,132-146.

[3] Brayfield, A.H. and Rothe, H.F. (1951) "An Index of job Satisfaction," Journal of Applied Psychology, 35, pp.307-311.

[4] Bruck, C. S., Allen, T. D., \& Spector, P.E. (2002). The relationship between work-family conflict and job satisfaction: A finner grained analysis. Journal of Vocational behavior, 60(3), 336-353. 
Examine The Mediating Effect of Work-Life Balance on the Relationship Between WorkFamily Conflict and Job Satisfaction of Women Doctors

[5] Burke, R.J., 2005. Work experiences and Psychological wellbeing of former hospital based nurses now employed elsewhere. Psychological Reports 91, 1059-1064.

[6] Chandra.V. (2012) Work-life balance: Eastern and western perspectives. The International Journal of Human Resource Management. 23, 1040-1056.

[7] Chernyak-Hai, L., \& Tziner, A. (2016).The "I believe" and the "I invest" of work-family balance: The indirect influences of personal values and work engagement via perceived organizational climate and workplace burnout. 32, 1-10.

[8] Clark, S.C. (2000). Work/family border theory: A new theory of work/family balance. Human relations, 53(6), 747-770.

[9] Clarke, M.C., Koch, L.C., \& Hill, E.J. (2004). The Work Family Interface: Differentiating Balance and Fit. Family and Consumer Sciences Research Journal, 33(2), 121-140.

[10] Clark, S.C. (2000). Work/Family border theory: A new theory of work/family balance. Human Relations, 53(6), 747-770.

[11] Frone, M.R., and Cooper, M.L. (1992), Antecendents and Outcomes of Work-family Conflict: Testing a Model of the Work-Family Interface, Journal of Applied Psychology, Vol.77, pp. 6578 .

[12] Frone, M.R.R. (2003). Work-family balance Handbook of Occupational Health Psychology. Washington DC: American Psychological Association.

[13] Greenhaus, J.H., and Beutell, N.J. (1985), "Sources of Conflict between Work and Family Roles". Academy of Management Review, 10, 1, 76-88.

[14] Greenhaus. J.H.,Collins, K.M., and Shaw, J.D. (2003). The Relation between Work-Family Balance and Quality of Life," Journal of Vocational Behavior, 63, 510-531.

[15] Haar, J.M., (2013), testing a new measure of work-lie balance: a study of parent and non-parent employees from New Zealand. The International Journal of Human Resource Management, Vol. 24, No. 17, 3305-3324.

[16] Hill, E.J.,Hawkins, A.J., Ferris, M., \& Weitzman, M. (2001). Findings an extra day a week: The positive influence of perceived job flexibility on work and family life balance. Family Relations, 50, 49-58.

[17] Hughes, D. L., \& Galinsky, E, (1994), Gender, job and family conditions and psychological symptoms. Psychology of Female Quarterly 18, 251-270.

[18] Karckay, A. T., \& Bakalim, O., (2017), the mediating effect of work-life balance on the relationship between work-family conflict and life satisfaction. Australian Journal of Career Development, Vol. 26 (1) 3-13.

[19] Kinnunen, U., \& Manuno, S. (1998). Antecedents and consequences of work-family conflict among employed female and men in Finland. Human Relations, 51, 157-177.

[20] Kirchmeyer.C (2000), "Work-life initiatives: greed or benevolence regarding workers time? Trends in organizational behavior, Vol.7, pp. 79-93.

[21] Kofodimos, J.R. (1993), Balancing Act, San Francisco, C.A: jossey- Bass.

[22] Kossek, E. E., \& Ozeki, C. (1998). Work-family conflict, policies and the job satisfaction relationship: A review and directions for organizational behavior-human resource research. Journal of Applied Psychology 83, 139-149.

[23] Kuzulu, E., Kurtuldu, S., \& Ozkan, G.V. (2013). Is Yasam Dengesi ile Yasam Doyumu IIiskisi Uzerine Bir Arastarma [A relationship between work-life balance and life satisfaction]. The Sakarya Journal of Economics, 2, 88-127.

[24] Locke, E. A. (1976), "The Nature and Causes of Job Satisfaction," in M.D. Dunnette (ED), Handbook of Industrial and Organizational Psychology, John Wiley and Sons, New York,pp. 1297-1349.

[25] Luthans, F. (1998), Organisational Behavior, $8^{\text {th }}$ edition, Irwin Mc Graw Hill, Boston. 
[26] Mesmer-Magnus, J.R., \& Viswesvaran, C. (2005). Convergence between measures of work to family and family to work conflict: A Meta analytic examination. Journal of Vocational Behavior, 67, 215-232.

[27] Michtalik, H.J., Yeh, H.C., Pronovost, P.J. and Brotman, D.J. (2013) 'Impact of Attending Physician Workload on Patient Care: A Survey of Hospitalists', JAMA Internal Medicine, and Vol. 173(5), pp. 375-377.

[28] Orrom, W.J. (2008) 'Achieving balance in a surgical life: A personal perspective on a Sisyphean task', The American Journal of Surgery, Vol. 195(5), pp. 557-564.

[29] Perrons, D. (2003), "The New Economy and the Work-Life Balance: Conceptual Explorations and a Case Study of New Media," Gender, Work and Organization. 10, 65-93.

[30] Purohit, Manisha (2013), “A Comparative Study of Work life Balance in Various Industrial sectors in Pune Region", International Journal of Marketing, Financial Services and Management Research, Vol.2,

[31] Redmond, J., Valiulis, M., \& Drew, E. (2006). Literature review of issues related to work-life balance, workplace culture and maternity/childcare issues. -3860 .

[32] Reich, R. (2001), The Future of success: Work and Life in the New Economy. London: Heinemann.

[33] Richard E. Kopleman, Jeffrey H. Greenhaus, Thomas F. Connolly (1983). A Model of Work, Family and Interrole Conflict: A Construct Validation Study. Organizational Behavior and Human Performance 32, 198-215.

[34] Spector, P. E., (2000), why negative affectivity should not be controlled in job stress research: don't throw out the baby with the bath water. Journal of Occupational Behavior, 21, 79-95.

[35] Tumulty, G., Jernigan, I.E., Kohut, G.F., 1994. The Impact of perceived work environment on job satisfaction of hospital staff nurses. Applied Nursing Research 7, 84-90.

[36] Vaclour, M. (2007), "Work-Based Resources as Moderators of the relationship Between Work Hours and Satisfaction with work-family balance," Journal of Applied Psychology, 92, 6, 15121523 . 